\title{
The Timber Footprint of the German Bioeconomy-State of the Art and Past Development
}

\author{
Vincent Egenolf ${ }^{1, *(\mathbb{D})}$, Gibran Vita ${ }^{1,2}$, Martin Distelkamp ${ }^{3}$, Franziska Schier ${ }^{4}$, Rebekka Hüfner ${ }^{1}$ \\ and Stefan Bringezu 1 (1) \\ 1 Sustainable Resource Futures Group (SURF), Center for Environmental Systems Research (CESR), \\ University of Kassel, 34117 Kassel, Germany; gibran.vita@gmail.com (G.V.); \\ rebekka.huefner@gmail.com (R.H.); bringezu@uni-kassel.de (S.B.) \\ 2 Environmental Sciences, Open University of the Netherlands, 6419 AT Heerlen, The Netherlands \\ 3 Gesellschaft für Wirtschaftliche Strukturforschung, 49080 Osnabrück, Germany; distelkamp@gws-os.com \\ 4 Thünen Institut für Internationale Waldwirtschaft und Forstökonomie, 21031 Hamburg-Bergedorf, Germany; \\ franziska.schier@thuenen.de \\ * Correspondence: vincent.egenolf@uni-kassel.de; Tel.: +49-561-804-6126
}

Citation: Egenolf, V.; Vita, G.;

Distelkamp, M.; Schier, F.; Hüfner, R.;

Bringezu, S. The Timber Footprint of

the German Bioeconomy-State of

the Art and Past Development.

Sustainability 2021, 13, 3878. https:/ /

doi.org/10.3390/su13073878

Academic Editor: Manfred

Max Bergman

Received: 2 March 2021

Accepted: 25 March 2021

Published: 1 April 2021

Publisher's Note: MDPI stays neutral with regard to jurisdictional claims in published maps and institutional affiliations.

Copyright: (C) 2021 by the authors. Licensee MDPI, Basel, Switzerland. This article is an open access article distributed under the terms and conditions of the Creative Commons Attribution (CC BY) license (https:/ / creativecommons.org/licenses/by/ $4.0 /)$.

\begin{abstract}
The article gives a comprehensive overview of the roundwood equivalents (RE) consumed in the German bioeconomy from Germany and abroad between 1995 and 2015, i.e., the Timber Footprint of final Consumption ( $\left.\mathrm{TFP}_{\mathrm{con}}\right)$. The calculation is based on an adapted version of Exiobase 3.4.

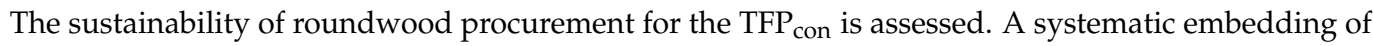
the tree compartments considered in the TFP in the context of national forest inventories and material flow analysis is presented. The results show that, in 2015, the total volume of the TFP con of Germany is $90 \mathrm{Mm}^{3}$ (slightly above the 1995 level) and is composed of $61 \%$ coniferous and $39 \%$ non-coniferous wood. Germany is strongly dependent on roundwood sourced from abroad and thus was a net importer of RE in 2015. Among the 17 countries with the largest supply of RE for the $\mathrm{TFP}_{\text {con, }}$ around one third very likely include large shares of roundwood procured from deforestation or clear-cutting. The self-sufficiency rate in 2015 was only $76 \%$. It would be possible to increase domestic roundwood production by $8-41 \%$ (mainly in the hardwood sector) without exceeding the sustainability limits as defined in the WEHAM scenarios.
\end{abstract}

Keywords: roundwood equivalents; supply security; environmental monitoring; environmental input-output analysis; sustainable consumption and production; resource footprints

\section{Introduction}

Growing population, increasing consumption and ongoing globalization result in an increase in global resource use [1]. One consequence of globalization is that the locations where goods are produced and consumed lie spatially far apart but are still linked by supply chains [2-4]. In light of a globalized economy, respecting planetary boundaries is a prerequisite for sustainable development [5]. Bioeconomy is proposed as one of the key strategies towards this end by improving and expanding the role of agriculture and forestry in meeting human needs while preserving healthy ecosystems [6].

According to the German Bioeconomy Council, the concept of bioeconomy comprises "the production and use of biological resources (including knowledge) in order to provide products, processes, and services in all economic sectors within the framework of a sustainable economic system" [7].

In Germany, a consortium of three projects characterizes the status quo of bioeconomy and proposes the development of a monitoring system to generate policy-relevant information. Within this context, the project "SYMOBIO_-Systemic monitoring and modelling the Bioeconomy" is developing a monitoring system and identifying key indicators for assessing the status of the bioeconomy with respect to social and environmental goals in line with the Sustainable Development Goals (SDGs) [8]. 
In this context, an "indicator system for assessing the sustainability of bioeconomy" has been published [9]. Following the Driver-Pressure-State-Impact-Response (DPSIR) Framework [10], resource inputs determine the scale of environmental impacts associated with extraction (input) and emissions (output). Resource and climate footprints quantify the resource throughput of a system. Steinmann et al. [11,12] show that the fossil energy, water, land and material footprint indicators are a good proxy for environmental impact.

The Timber Footprint (TFP) is major component of the aforementioned material footprint and a relevant indicator for assessing the sustainability of a bioeconomy [9]. Global forests play a fundamental role in the provision of ecosystem services and the protection of biodiversity, climate, water and soil and are therefore a topic of high priority in international studies $[13,14]$. In particular, the systemic interactions of individual factors, e.g., biodiversity and ecosystem services, are the subject of intensive research [15-17]. It is of global interest to keep forests intact and healthy, as stated by goal 15, "Life on Land", of the SDGs [13]. Harming these ecosystems through overuse can have serious consequences on a local and global scale. Around $45 \%$ of terrestrial carbon is stored in forest biomass [18]. Regarding climate change, deforestation contributes to a carbon loss of the soil [19], increases $\mathrm{CO}_{2}$ emissions [20] and leads, especially in tropical and temperate zones, to a decreased cooling effect [21]. In addition, deforestation has serious consequences, such as the loss of biodiversity and extinction of species [22,23].

Buongiorno et al. [24] predict an increase in global roundwood demand by around $44 \%$ from 2005 to 2030 following the IPCC scenario A1B with a strong increase in wood used for energy production (fuelwood). A second study by Buongiorno [25], based on the IPCC B2 scenario, predicts an increase in roundwood production of around $61 \%$ between 2001 and 2065. Furthermore, the Food and Agricultural Organization of the United Nations (FAO) [26] predicts an increasing demand for fuelwood, likely rising globally from $2 \mathrm{Gm}^{3}$ in 2005 to $3 \mathrm{Gm}^{3}$ in 2030. These predictions are supported by single country studies as conducted in Sweden [27] and Finland [28]. The actual developments are strongly influenced by political targets, such as the revised renewable energy directive of the EU [29].

It is likely that the predicted increase in the demand for roundwood will result in an increased use of forest resources [30]. This additional forest resource use could have an influence on the provision of forest ecosystem services depending on the type of forest [31,32] and forest management $[33,34]$.

In 2020, 4.06 billion ha of forests covered 30.8 percent of the world's land area and provided direct sustenance to two billion people. Tropical and subtropical forests comprised 56 percent of the forest area, while temperate and boreal forests accounted for the rest. Natural regenerating forests were estimated to constitute around 93 percent of global forests, while planted forests constitute around 7 percent [35].

The 2020-released State of the World's Forest Report from FAO and UNECE [35] shows the diversity of damage impacts on global forests. These are often forest-type-specific and vary greatly between ecoregions and climate zones. While the net global loss of forest cover has declined significantly since 1990, more than 6 million hectares of forest area were lost annually in the Global South between 2010 and 2020. In Africa, there is even an increasing trend, with around 20\% more forest area loss between 2010 and 2020 compared to $1990-2000$ [35]. Here, more than $50 \%$ is driven by the production of fuelwood and charcoal [36]. Just over one quarter of global forest loss is driven by deforestation, out of which $95 \%$ occurs in the tropics, where Brazil and Indonesia alone account for nearly half of this share [37]. In contrast, two thirds of forest degradation occurs in temperate countries. High-latitude forests are increasingly threatened by fire [38] and temperate forests by pests [39].

For monitoring, it is necessary to use indicators that allow direct comparison of the different regions of origin, despite the variety of forest management systems [40] and accounting methods [41]. Typical census issues are that top-down satellite images are hard to reconcile with official statics, which only consider deforestation as change in land use, not harvesting from forest plantations. 
In this study, the indicator Timber Footprint of German final consumption of roundwood equivalents $\left(\mathrm{TFP}_{\mathrm{con}}\right)$ is chosen, which allows quantification of the RE sourced from within and outside Germany and a subsequent assessment of the respective region of origin. This article shows the development of the Timber Footprint of Germany from 1995 to 2015, identifying the source countries, and respective quantities, which originate from these countries. Two different methods are used to assess the sustainability of the respective source regions of final RE consumption in Germany. The first method uses statistical information from international reports such as the Global Forest Resource Assessment [42], The State of Europe's Forest Report [43,44] to calculate the country- or region-specific ratio of annual roundwood removal to annual net increment. This "forest utilization rate" is a common indicator reported, for example, by the EEA [45]. The second method combines spatially explicit information on annual forest area loss [46], growing stock volume [47] and the underlying dominant driver of forest loss [37] to calculate the amount of roundwood gained from deforestation and clearcutting practices that serves as a proxy for high environmental impacts.

Our analysis answers the question of whether the German roundwood demand can be satisfied self-sufficiently and sustainably. We also identify regions where roundwood sourcing could be critical for a sustainable bioeconomy.

\section{Materials and Methods}

\subsection{General Approach}

A systematic embedding of the tree compartments considered in the quantification of the TFP in the thematic framework and respective nomenclature of National Forest Inventories and material flow analysis is presented (Section 2.2). The amount of final consumption and total throughput of RE by the German bioeconomy is calculated (Section 2.3). The sustainability of the footprint and the regions of origin is evaluated (Section 2.4).

\subsection{Forest Material Accounting for the Timber Footprint}

A systematic overview of the allocation of tree components to use categories and the respective terminology commonly used in national and global forest inventories [48-50], material flow analysis indicators [51-53] and plant ecology [54] is presented in Figure 1.

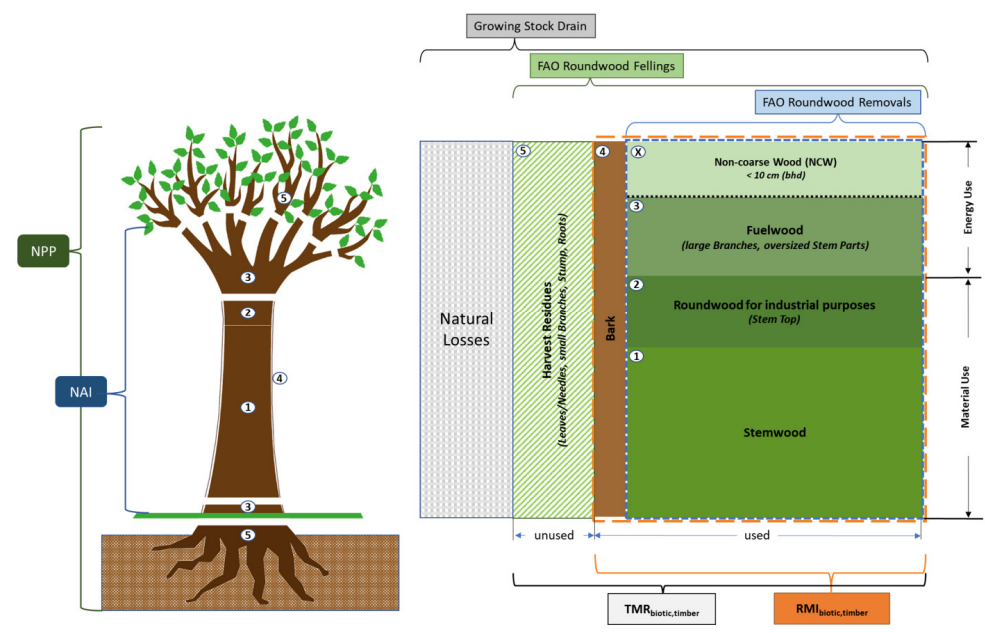

Figure 1. Systematic overview of the allocation of tree components to a usage category adopting forestry terminology and material flow analysis indicators. A glossary is attached in the Supplementary Information I. The white spaces indicate the cut between different categories of roundwood, which are marked with the respective number (1-5). Category $X$ is not apparent in the tree visualization, as it consists of non-coarse wood that is not further subdivided at harvest. The green line symbolizes the typical felling cut during the wood harvest. Natural losses are not recoverable and therefore not allocated to a usage category. The TFP as calculated in this paper consists of the categories $1-3$ and $X$. 


\subsubsection{Timber Footprint (TFP)}

The quantity of wood accounted for in the TFP as it is presented in this study has the unit roundwood equivalents under bark (u.b.) and comprises the same tree parts as the FAO "Roundwood Removals" (categories 1-3 and X).

\subsubsection{Roundwood Equivalents (RE)}

The term roundwood equivalent u.b. (RE), as used in this study, reflects a theoretical volume of roundwood under bark necessary as input to produce the specific output of each economic sector included in the multi-regional input-output database (MRIO). Depending on the sector considered, these RE are physically visible (e.g., furniture sector) or a theoretical attribution (e.g., services sector).

\subsubsection{Terminology of Forest Inventories for the Present Study}

The different tree parts are allocated to different categories. Tree stems are classified as (1) Stemwood and Treetops to (2) Roundwood for Industrial Purposes. Both categories are used for material purposes. Large branches and oversized stem parts are allocated to (3) Fuelwood and used for energy purposes. The three categories (1,2 and 3) fit into the growing stock definition of the FAO [55] with a given diameter at breast height (dbh) of $\geq 10 \mathrm{~cm}$. Trees with a dbh diameter of $<10 \mathrm{~cm}$ are defined as non-coarse wood (category $X$ ). If these are felled, e.g., for stock thinning purposes, the biomass is used for energy purposes as in category 3.

The sum of the categories $1-3$ and X is reported as "Roundwood Removals" in the FAO database. Per definition, stumps and roots would be considered under this term too if they are removed from the forest, but since their large-scale harvest is rather uncommon in most of the European countries today, they are excluded from Figure 1 for visualization purposes [56].

Since Roundwood Removals are reported in $\mathrm{m}^{3}$ under bark (u.b.), category 4 (bark) is not included. Category 5, "Harvest Residues", consists of leaves, needles, small branches, stumps and roots. These are tree parts which are not removed from the forest in a typical harvest scheme. The term Roundwood Fellings, defined by FAO, comprises the roundwood volume removed from the forest (Roundwood Removals u.b.) as well as bark and the harvest losses, which remain in the forest. On the growth side, the term Net Annual Increment (NAI) is used to determine the volume of roundwood over bark (o.b.) by which the stock increases annually, taking into account the impact of natural events and human harvesting.

\subsubsection{Terminology of Material Flow Analysis (MFA) for the Present Study}

The two indicators Raw Material Input (RMI) and Total Material Requirement (TMR) are derived from economy-wide material flow accounting [51-53]. The RMI accounts for the used extraction of biotic and abiotic raw materials and the TMR additionally considers the unused extraction. Figure 1 exclusively considers the timber shares of RMI and TMR. For the calculation of the MFA indicators, a conversion from wood volume to mass using the wood-species-specific density is required. The sum of the categories 1-4 and X can be allocated to the indicator Raw Material Input of timber ( $\left.\mathrm{RMI}_{\text {biotic, timber }}\right)$. If the biomass comprised in category 5 (harvest losses) is added, the indicator Total Material Requirement of timber $\left(\mathrm{TMR}_{\text {biotic, timber }}\right)$ is obtained. A detailed description of the implementation of the Timber Footprint in life cycle analysis (LCA) software will be presented in an additional publication.

\subsubsection{Terminology of Plant Ecology for the Present Study}

The Net Primary Productivity (NPP) is the sum of all carbon fixed by plants via photosynthesis minus the carbon loss through respiration, root exudates and volatile organic carbon emissions. 


\subsection{MRIO Analysis}

\subsubsection{Footprint Calculation with Exiobase 3.4}

In recent years, different multi-regional input-output databases for footprint analysis have been created, e.g., Exiobase [57], GTAP [58], WIOD [59] and EORA [60]. These databases can be used to quantify the product flows within and between countries. In addition, the environmental extensions of these databases contain information about resource extraction, emissions and waste disposal for the respective countries. It is therefore possible to trace the environmental impacts of final product consumption in one country back to their origin in other countries.

The environmentally extended input-output matrix Exiobase 3.4 [61] is used as a base for the footprint calculation [57]. $A$ is the matrix of input coefficients, $x$ is the n-element column vector of the outputs and $y$ the n-element column vector of the total final demand. The isolation of the output vector $x$ results in

$$
x=(I-A)^{-1} y
$$

The matrix $(I-A)^{-1}$ is called Leontief inverse. Given that the final demand $y$ and the coefficient matrix $A$ are known, the sectoral outputs $x$ can be calculated as the total economic output of a respective sector in a respective nation as a function of the final demand $y$ of the consuming nation. The final demand of RE of the German bioeconomy is calculated by the standard Leontief input-output model [62]. The resources included in the Timber Footprint are stated in Table 1.

Table 1. Conceptual coverage of the Timber Footprint $\left(\mathrm{m}^{3} \mathrm{RE}\right)$ of Exiobase 3.4.

\begin{tabular}{ccc}
\hline Footprint & Coverage & Source \\
\hline Timber Footprint & $\begin{array}{c}\text { Used Domestic Extraction of: } \\
\text { Industrial Roundwood Coniferous } \\
\text { Industrial Roundwood Non-Coniferous } \\
\text { Woodfuel Coniferous } \\
\text { Woodfuel Non-Coniferous }\end{array}$ & $\begin{array}{c}\text { Exiobase 3.4 adapted by } \\
\text { a nowcasting process }\end{array}$ \\
\hline
\end{tabular}

The Timber Footprint of Consumption (TFP $\mathrm{T}_{\mathrm{con}}$ ) is obtained by adding the mass of extracted roundwood within the national territory to the quantity of RE extracted abroad to satisfy the domestic consumption of products and services, and then deducting the quantity of domestically extracted RE used for export. Without the deduction, the Timber Footprint of Production (TFP $\mathrm{p}$ ) is obtained, which quantifies the total throughput of RE of the German production system.

\subsubsection{Adaptation of Exiobase 3.4 for This Study by Nowcasting}

The multi-regional input-output database (MRIO) EXIOBASE v3.4 [61] covers the years from 1995 and up to 2011. In order to take into account recent, already known developments, the MRIO data (including the satellite accounts) are extended up to 2015, based on available statistical information, with a focus on data relevant for the bioeconomy.

This nowcasting approach first consolidates the 200 product groups contained in the original Exiobase 3.4 MRIO database into an aggregated version with 62 product groups. This step reduces the number of matrix elements by a factor of 10 and thus enables a much more flexible handling for nowcasting and forecasting experiments. The aggregation scheme for consolidation is designed in such a way that the bioeconomic parts of the MRIO remain unaffected. Comparisons for footprint indicator assessments based on the consolidated MRIO show deviations of below 1\% from the original solution. The major aspects and data foundations for the nowcasting of the MRIO data for all 44 countries and 5 Rest of World regions (ROW) are time series information for 2011 to 2015 on the following aspects: 
1. Production quantities of crops and wood on basis of FAOSTAT that are reported in the satellite accounts of the MRIO and that are key for the material flow analysis;

2. GHG emissions-where possible, differentiated for industries-on basis of Eurostat and UNFCCC data that are also reported in the satellite accounts of the MRIO and that are key for the assessment of GHG footprints;

3. Macro-economic indicators (e.g., the final consumption expenditures by household) and Non-Profit Institutes Serving Households (NPISH) on basis of Worldbank data for the prolongation of the final demand blocks of the MRIO;

4. Gross output at current prices for the agricultural sub-sectors on the basis of FAOSTAT for the adjustment of MRIO rows for these sub-sectors.

\subsection{Sustainability Assessment of the Timber Footprint}

\subsubsection{Net Annual Increment}

The average values of net annual increment (NAI) $\left(\mathrm{m}^{3} / \mathrm{ha}^{-1} \mathrm{y}^{-1}\right)$ are taken from the Global Forest Resource Assessment (FRA) report [42] and the SOEF 2015 report [43]. If different figures are given in the two reports, the mean value of the two reports is used. In cases where just one report states a value, this value is used. Where none of the reports gives a value, the FAO continental average increment rates are used $[63,64]$, which is the case for Australia, Canada, India and Mexico. See Supplementary Information II for details.

The forest area available for wood supply (FAWS) (ha) was taken from O'Brien [64] based on the State of Europe's Forests 2011 [65] and State of the World's Forests 2011 [66]. By multiplying the NAI with FAWS, the total annual increment volume at country level is determined.

\subsubsection{Roundwood Removal Adjustment $\left(R_{A}\right)$}

The FAO values are reported in roundwood removals under bark. Therefore, we add $12 \%$ bark and $10 \%$ harvest residues as a Roundwood Removal Adjustment $\left(R_{A}\right)$ in order to be consistent with the quantity of net annual increment. The $R_{A}$ value of $22 \%$ is derived from different literature sources (Supplementary Information III).

\subsubsection{Sustainable Sourcing of Roundwood}

The ratio of the average total roundwood removals adjusted with $R_{A} 22 \%$ (Section 2.4.2) and the total annual increment volume determines the use intensity of the forest. A use intensity of less than $95 \%$ of NAI is considered sustainable (non-critical), between $95 \%$ and $105 \%$ of limited sustainability (possibly critical) and $>105 \%$ unsustainable (critical).

\subsubsection{Forest Growth Utilization Rate}

The mean forest growth utilization rate of Germany is calculated by the ratio of roundwood removals (RR) and the net annual increment. This indicator is used according to the indicator "forest utilization" of the EEA [67]. Therefore, the reported roundwood removal u.b. values are adjusted using Roundwood Removal Adjustment $R_{A} 22 \%$ as in Section 2.4.2. The roundwood removals are taken from the FAOSTAT database [44]. The net annual increment is reported by the German Ministry of Food and Agriculture [68].

\subsubsection{Self-Sufficiency Rate}

The self-sufficiency rate of Germany is the ratio of $\mathrm{TFP}_{\text {con }}$ to domestically sourced wood, following the equation provided by [69]. The quantity of domestically sourced roundwood is taken from FAOSTAT and the $\mathrm{TFP}_{\text {con }}$ is based on our own calculations in Section 2.3.

\subsubsection{Deforestation Wood as Possible Source for the TFP}

The quantity of roundwood from clear-cutting and deforestation procurement practices $i$, as defined by Curtis et al. [37], of a respective country or region $c$ is calculated as $D W_{c, i}\left(m^{3}\right)$ by the following steps: 
1. The annual global area of forest loss per year displayed as a raster layer with a highresolution grid of $30 \mathrm{~m}$ was published by Hansen et al. [70]. The data are freely available for the period 2000-2019 on the website operated by the University of Maryland [46]. For this study, information is filtered by deforestation events $D A_{+}$ that occur between 2010 and 2015. Cells without deforestation events are classified as $D A_{0}$. The layer is then aggregated to a resolution of $100 \mathrm{~m}$ using $\mathrm{R}$ Version 3.6.1. The result is a new raster layer $\mathrm{X}$ showing the share of deforestation area $D S$ per $100-\mathrm{m}$ cell in the observed period.

$$
D S=\frac{\sum_{i}^{n} D A_{+}}{\sum_{i}^{n} D A_{+}+\sum_{i}^{n} D A_{0}}
$$

2. This layer $X$ is then overlaid with a raster layer showing the growing stock volume GSV $\left(\mathrm{m}^{3}\right)$ per cell at a resolution of $100 \mathrm{~m}$ for the base year 2010, published by Santoro [47] using QGIS Version 3.14.16. By combining the two layers, we obtain a new layer $\mathrm{Y}$ showing the amount of wood procured through deforestation and clear-cut operations $D W\left(\mathrm{~m}^{3}\right)$ per $100-\mathrm{m}$ cell during the observed period.

$$
D W\left(m^{3}\right)=D S * G S V\left(m^{3}\right)
$$

In the next step, this layer $\mathrm{Y}$ is then aggregated using resampling (aggregation method = sum, weight according to the area) to a resolution of 5 arc-minutes using QGIS Version 3.16.

3. Curtis et al. [37] identified the dominant drivers of global forest loss from five different categories $i$ (commodity-driven deforestation, shifting agriculture, forestry, wildfires and urbanization) for the time period 2001-2015. The information is available as a raster layer with a resolution of $10 \mathrm{~km}$. For this study, the category wildfire is excluded from analysis based on the assumption that wood affected by forest fire is not subsequently used. The existing layer is resampled to the resolution of 5 arcminutes (aggregation method = average, weight according to the area) using QGIS Version 3.16 resulting in the layer $Z$.

4. A global 5-arc-minutes point shapefile is used to link layer $Y$ and $Z$ information to each point coordinate of a respective country or region of origin $c$ using the GRASS point sampling tool of QGIS Version 3.14.16. The result is then summed to a country or region resolution using R Version 3.0.4 and divided by six to obtain the annual total volume of roundwood procured on deforestation or clear-cutting areas $D W_{c, \text { total }}\left(\mathrm{m}^{3}\right)$ or the driver-specific volume $D W_{c, i}\left(m^{3}\right)$.

$$
D W_{c, \text { total }}\left(m^{3}\right)=\sum_{i}^{n} D W_{c, i}\left(m^{3}\right)
$$

5. The resulting annual quantity of $D W_{c, t o t a l}\left(m^{3}\right)$ is then compared to the official $R_{\mathrm{A}}$ $22 \%$-adjusted annual roundwood production of the respective country or region provided by FAOSTAT [44].

\section{Results}

The German Timber Footprint of Production $($ TFP $p$ ) for the year 2015 was calculated at $129 \mathrm{Mm}^{3}$ (Figure 2). According to our results, 53\% of the RE of the TFP $p$ is domestically sourced. Around $47 \%$ of the resources in the TFP $p$ are sourced in foreign regions. Among the foreign suppliers of RE, Europe provides 29\%, Africa 8\%, Asia 4\%, America 6\%, and the Middle East delivers less than $1 \%$ of the resources consumed in Germany. The major part of the domestically sourced RE (66\%) in Germany stays in the country instead of being exported. This corresponds to $50 \%$ of the German footprint of final consumption $\left(\right.$ TFP $\left._{\text {con }}\right)$. Thirty-four percent of the domestically sourced RE is exported. As imports exceeded exports by $56 \%$, Germany was a net importer of RE in 2015. We calculated the German 
self-sufficiency rate [69] in 2015 as 76\%. The mean self-sufficiency rate between 1995 and 2015 was $67 \%$.

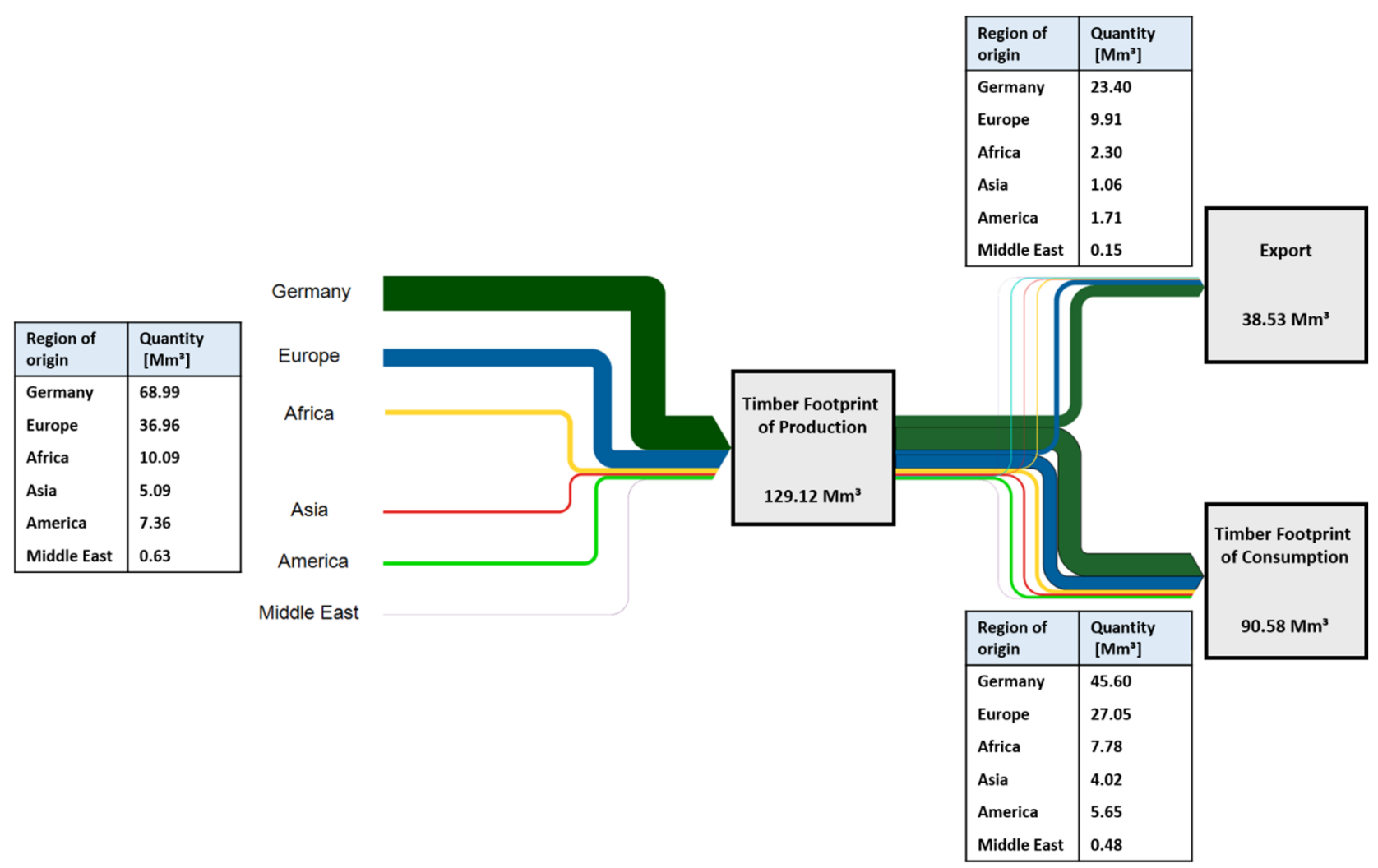

Figure 2. Visualization of the $\mathrm{TFP}_{\mathrm{p}}$, the $\mathrm{TFP}_{\text {con }}$ and exports of roundwood equivalents u.b. of Germany in 2015 based on the nowcasted version of Exiobase 3.4. The Sankey diagram was produced using e!Sankey 4 pro. Underlying data are provided in the Supplementary Information IV.

The Timber Footprint of Production (TFP $)$ shows a strong increase in the first five years of the examined period, while in the following years, we observe a fluctuating trend caused by severe storm events. The mean is around $136 \mathrm{Mm}^{3}$ between 2000 and 2015 (Figure 3). In 1995, the export has a share of $17 \%$ of the total footprint of production, which doubles in the next decade. Between 2005 and 2015, exports remain at around 30\% of the total footprint of production. Germany becomes more export-oriented in the total examined period, with an export increase by around $130 \%$. The resource productivity (GDP/Resource Input) increases by around 30\% within this timeframe-presumably driven by increased exports.

The development of the TFP ${ }_{\text {con }}$ of Germany between 1995 and 2015 shows a fluctuating trend (Figure 4). The TFP con in 2015 is, with around $90 \mathrm{Mm}^{3}$, only slightly higher (10\%) than in 1995. The share of RE sourced within German territory of the total TFP ${ }_{\text {con }}$ increases from $40 \%$ in 1995 to $50 \%$ in 2015 . The mean of $\mathrm{TFP}_{\text {con }}$ between 1995 and 2015 consists of $57 \%$ coniferous wood and $43 \%$ non-coniferous wood. There are two peaks visible in 2000 and 2007, both followed by a strong decline, explained by the hurricanes "Lothar" and "Kyrill", as a result of which millions of cubic meters of roundwood had to be removed from the forest, increasing the share of domestic extraction in the footprint. 


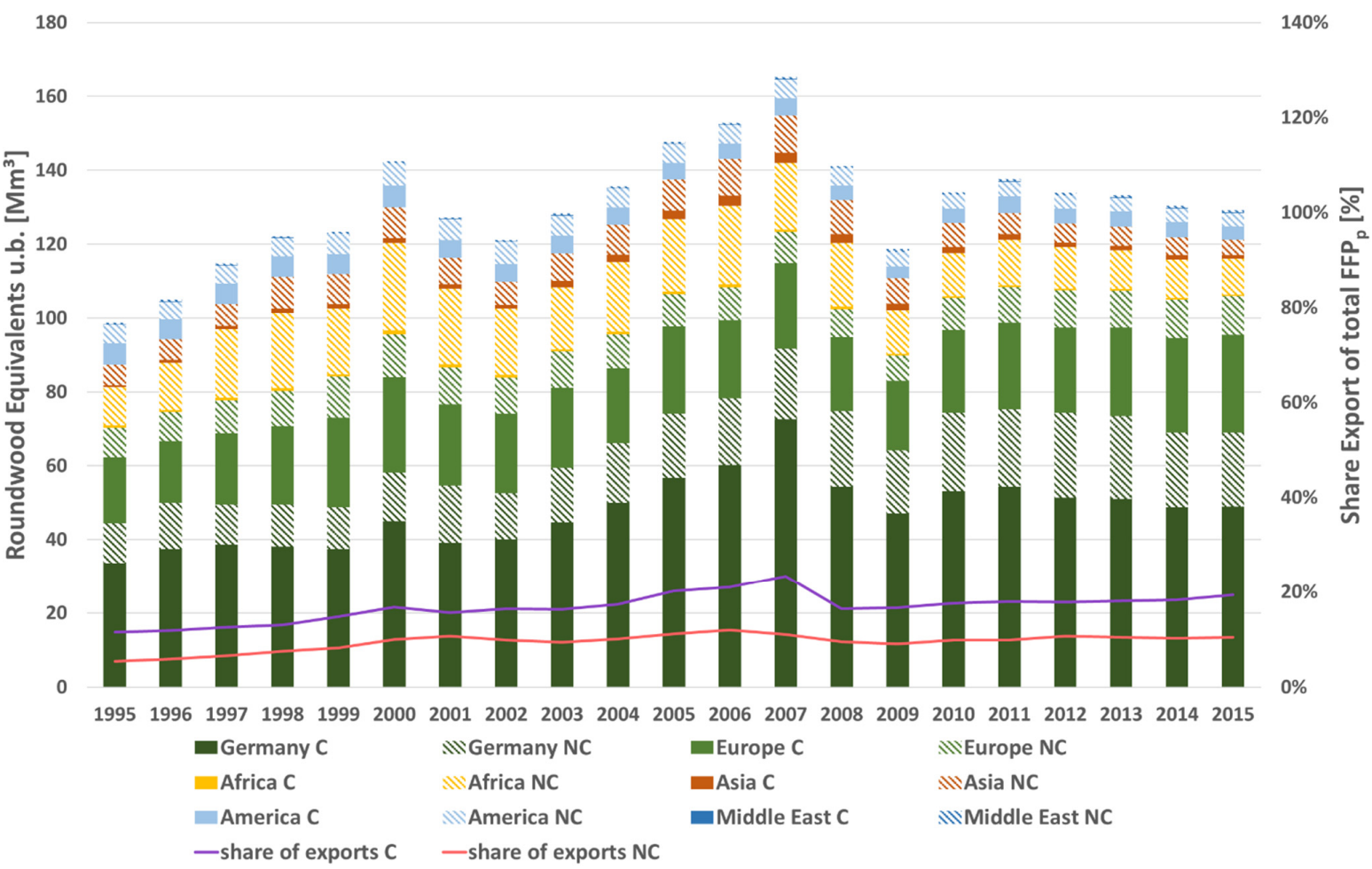

Figure 3. Development of the $\mathrm{TFP}_{\mathrm{p}}$ and exports of roundwood equivalents u.b of Germany between 1995 and 2015 based on Exiobase 3.4; the filled area " $\mathrm{C}$ " represents coniferous wood (softwood) while the hatched area "NC" represents non-coniferous wood (hardwood). Underlying data are provided in the Supplementary Information IV.

120

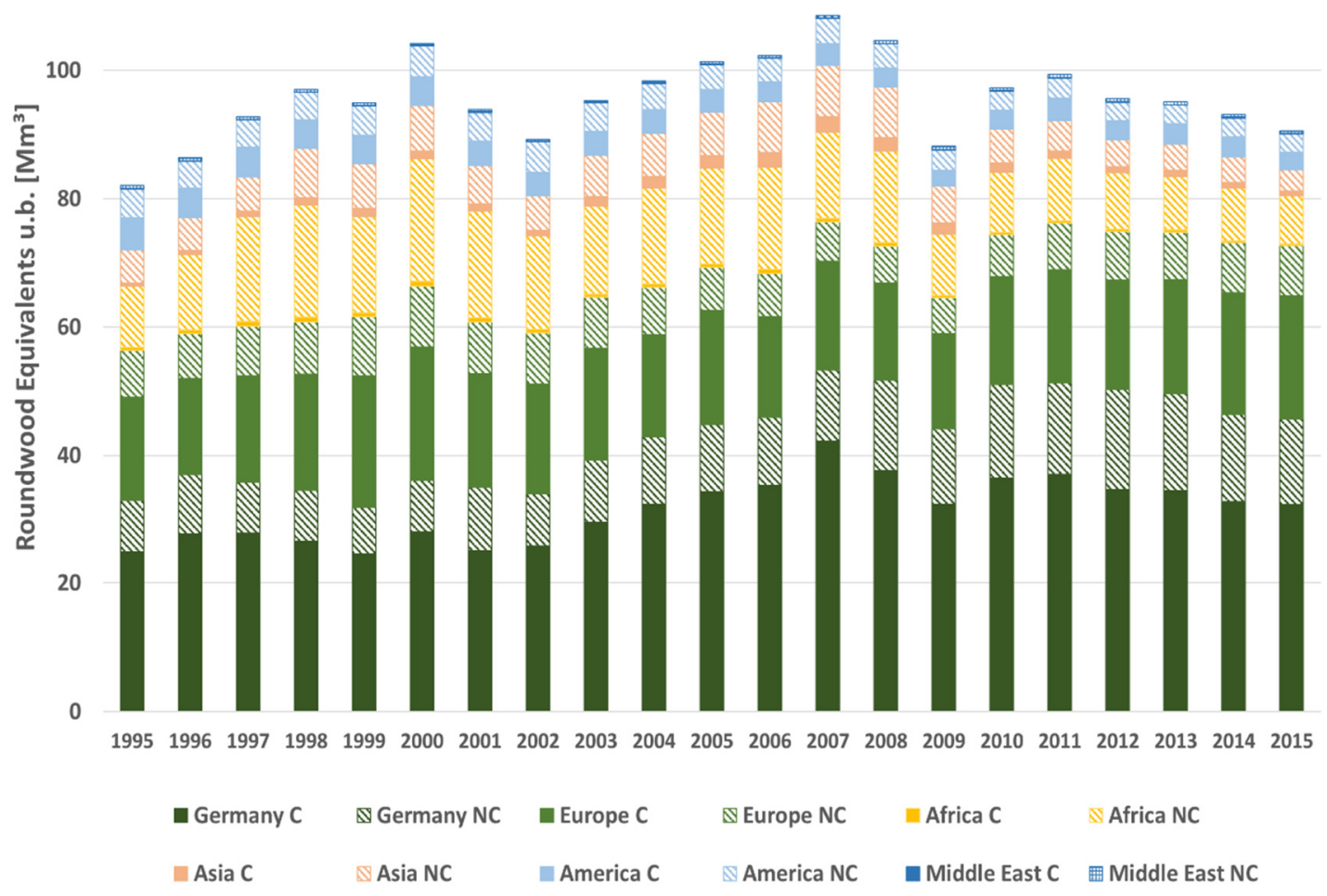

Figure 4. Development of the $\mathrm{TFP}_{\text {con }}$ of roundwood equivalents u.b of Germany between 1995 and 2015 based on Exiobase 3.4; the filled area " $\mathrm{C}$ " represents coniferous wood (softwood) while the hatched area "NC" represents nonconiferous wood (hardwood). Underlying data are provided in the Supplementary Information IV. 
Between 2010 and 2015, the RE sourced from Europe for the consumption in Germany increased by $15 \%$, while domestically sourced RE declined by $11 \%$. The amount of wood sourced from Africa and Asia strongly decreased over the last decade, namely by $50 \%$ and $54 \%$, respectively. At the same time, the amount of wood from America and Middle East remained relatively constant.

The mean total forest growth utilization in Germany between 2005 and 2015 adjusted for bark and harvest losses with $\mathrm{RR}_{\mathrm{A}} 22 \%$ following Section 2.4.2 is shown (Figure 5). The growth utilization rate value lies at $77 \%$. Figure 5 further highlights that coniferous wood has a higher growth utilization rate (86\%) than non-coniferous wood (61\%). A comparison of the abovementioned results with the average annual projected roundwood potential between 2013 and 2052 obtained from the WEHAM scenarios Nature Preference Scenario (NPS) and Wood Preference Scenario (HPS) [71] shows that an increase in annual roundwood production of between 8 and $41 \%$ would be possible without violating the SOS, mainly in the non-coniferous (hardwood) sector.

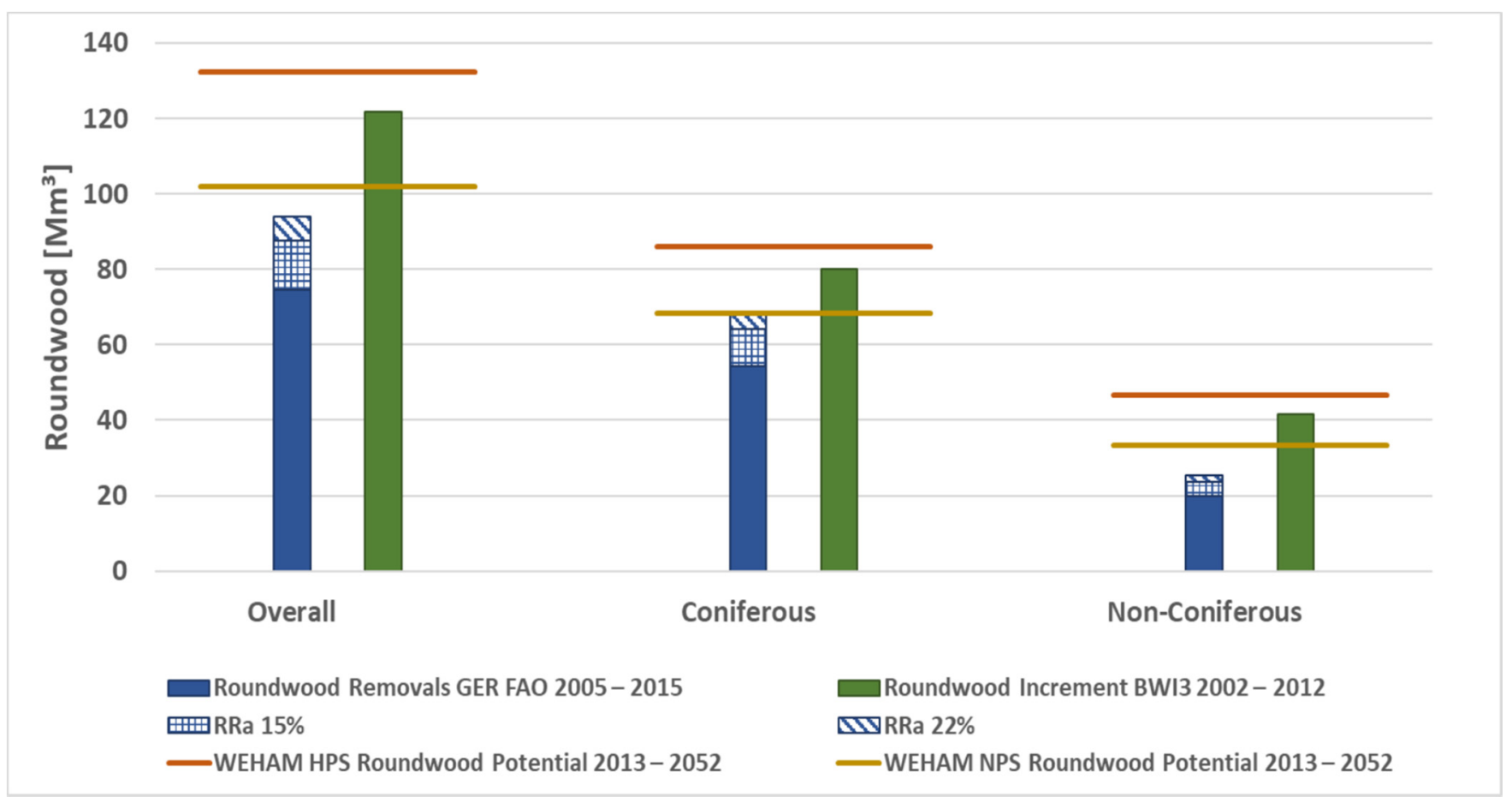

Figure 5. Average forest growth utilization between 2005 and 2015. The data for the average roundwood removals are taken from FAOSTAT; data are adjusted by $\mathrm{RR}_{\mathrm{A}} 22 \%$ [72] to account for the bark and harvest residues. The scenario data are taken from the alternative WEHAM scenarios as average values between 2013-2052 [71] and RR $22 \%$ is applied. The average annual increment is taken from BWI3 (BMEL, 2014). Sources for the $R_{\mathrm{A}} 22 \%$ value are shown in Supplementary Information III. Underlying Data are provided in the Supplementary Information IV.

The sustainability of supply is assessed by combining information about the conditions of resource mobilization in the country of origin with the amount of RE sourced for German consumption (Figure 6). The three categories "TFP ${ }_{\text {con }}$ of a sustainable origin" (greens), "TFP ${ }_{\text {con }}$ of a questionable sustainable origin (yellows) and "TFP $\mathrm{T}_{\text {con }}$ of presumably unsustainable origin" (reds) are visible. According to our analysis, most countries in Europe can be classified as sustainable sources for wood. Exceptions are Ireland and Estonia, which are categorized as questionable sources of sustainable harvested roundwood. Based on the data used, roundwood production exceeds the annual increment in Sweden and Belgium. These countries are therefore classified as "presumably unsustainable" sources of roundwood. Our analysis shows America, but not Mexico and Brazil, as a sustainable source of roundwood. In contrast, the continent of Africa and most parts of Asia and 
Oceania cannot be classed as sustainable sources of roundwood. The underlying data for the calculation are provided in Supplementary Information II.
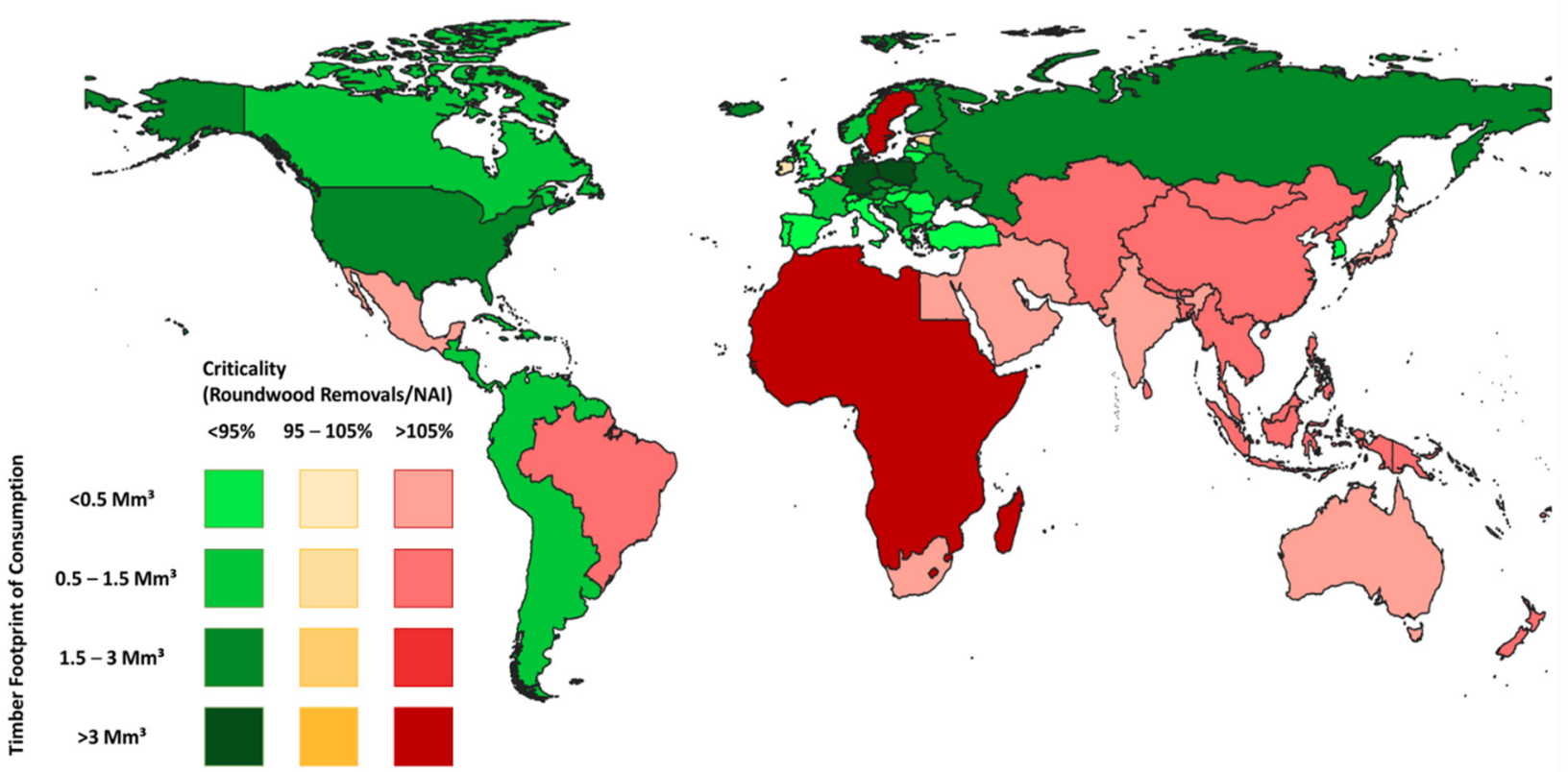

Figure 6. Mean Timber Footprint of final consumption TFP con of Germany between 2005 and 2015 based on a nowcast version of Exiobase 3.4 evaluated by the ratio of roundwood removals to net annual increment. The roundwood removals are adjusted by using the $\mathrm{RR}_{\mathrm{A}} 22 \%$. The figure was produced with QGIS version 3.14. Underlying data are provided in the Supplementary Information IV.

The 17 foreign regions that each supply more than one million $\mathrm{m}^{3}$ of RE per year between 2010 and 2015 to the German TFP con are analyzed in terms of their annual wood procurement volume through deforestation and clear-cut operations as defined by Curtis et al. [37] and the official quantity of annual roundwood removals reported by FAOSTAT (Figure 7). The analysis assumes that the wood from forest area clearing is used for energy or material purposes regardless of the reason for the clearing. Two thirds of the German wood suppliers use predominantly procurement practices that lead only to short-term loss of forest area, such as by forestry clear-cutting. However, this does not hold for ROW Asia and Pacific, ROW America, ROW Africa, Brazil and Indonesia. Here, large forest areas are cut down due to shifting agricultural practices (SA) or commodity-driven deforestation (CDD) (e.g., palm oil plantations, mining). The difference between CDD and SA is that the latter shows a regrowth of forest after a short to medium period of time, whereas CDD does not show forest regrowth, not even in the longer term. The commoditydriven deforestation may account for up to $41 \%$ (ROW Asia and Pacific), $49 \%$ (ROW America), 62\% (Brazil) and 199\% (Indonesia) of the officially reported amount of roundwood removals (adjusted with $\mathrm{RR}_{\mathrm{a}} 22 \%$ ) from FAOSTAT. For ROW Africa, agricultural shift seems to be a major driver of forest area conversion and consequently a source of wood, with an attributable share of around $44 \%$. 


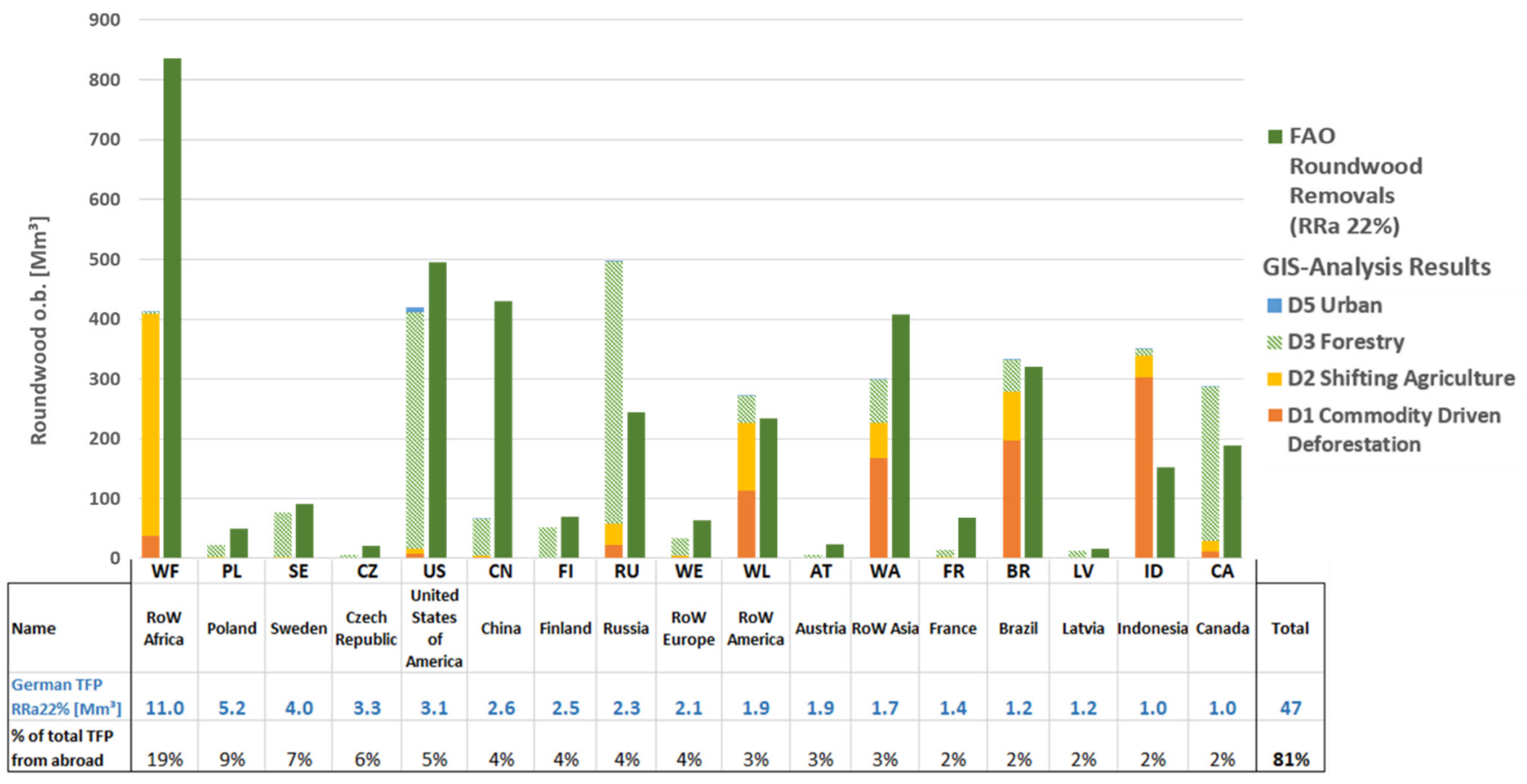

Figure 7. Comparison of procured roundwood o.b. on deforested and clear-cut areas (GIS analysis) with officially reported roundwood removals (FAOSTAT) of the 17 largest suppliers to the German $\mathrm{TFP}_{\text {con }}$ from abroad, averaged from 2010 to 2015. The dark green column shows the official data from FAOSTAT adjusted for bark and harvest losses with $R_{\mathrm{a}} 22 \%$. The stacked columns show the result of the GIS analysis combined with the deforestation and clear-cut driver information from Curtis et al. [37]. The underlying data can be found in Supplementary Information IV.

\section{Discussion}

\subsection{Implications for Germany}

On the basis of the calculated forest growth utilization rate for 2015, it would be possible to increase the amount of domestic roundwood production without exceeding sustainability limits. The comparison with the alternative WEHAM scenarios [71], namely the Nature Preference Scenario (NPS) and Wood Preference Scenario (HPS), shows that an average annual increase of between 8 and $41 \%$ would be possible without violating sustainable conditions. The forest growth utilization rate is higher for coniferous wood than for nonconiferous wood (Figure 5 ) and the total TFP $p$ shows a strong dependency on coniferous roundwood (Figure 3), which is also stated by Weimar [73]. This dependency entails risks. Coniferous trees are shallow-rooted and, despite progressive forest restructuring measures in German forests, still dominant as monocultures [74]. This makes them vulnerable to natural phenomena such as storms [75] and pest infestation (e.g., bark beetles) [76-78]. The increased forest damage due to calamities under the hurricanes Lothar in 1990 and Kyrill in 2007 underline the risks. The impact of these two hurricanes can be seen directly in the sharp increase in the volume of domestically sourced roundwood in 2000 and 2007, followed by a sharp decline over three years, resulting in the fluctuating trend shown in Figures 3 and 4 . This results from the fact that calamity wood must be quickly removed from the forest to prevent beetle propagation [79], even if there is no market demand for further use.

It must be mentioned that recent damages due to the dry summers in 2018 and 2019 and the hurricane Friederike are not reflected in our data. The forest condition report of 2020 of the Federal Ministry of Food and Agriculture (BMEL) [39] shows that 37\% of the trees suffered severe effects of drought in 2020 (36\% in 2019 [80]), which is an increase of $8 \%(7 \%)$ from $2018[39,80]$. In the case of spruce, the proportion of significant crown thinning rose by $19 \%$ from 2018 to 2020 . Only $21 \%$ of the pine trees showed no signs of crown thinning in 2020 , which is the lowest percentage ever recorded for this species $[39,80]$. Similar trends 
can be observed in many other European countries, with around $26 \%$ of all trees showing a defoliation stage above the warning level in 2018 [40]. As climate change intensifies [81-83], it is becoming increasingly difficult to meet the demand for coniferous wood within German territory as the growing conditions deteriorate. To counteract this, forest restructuring through natural regeneration and the replacement of coniferous monocultures with mixed forests are being implemented as climate adaptation measures to cope with the risks of global warming [84,85].

\subsection{Implications of the German TFP con for Countries Abroad}

According to our calculations, around half of the wood of the German $\mathrm{TFP}_{\text {con }}$ in 2015 was sourced from domestic territory. The other half stemmed from foreign territory, where the sustainability of wood procurement practices and forest management bear the risk of violating sustainability rules. This applies particularly to the Global South, i.e., Africa, Brazil and South-East Asia. Our results assign Sweden to the category of non-sustainable roundwood procurement (Figure 6). This does not appear to be intuitive and may be partly caused by data uncertainties. However, a recent study confirms problems in the Swedish forest sector in the sense that Sweden has the highest loss of forest area in Europe and saw an increase in harvested forest biomass of around 70\% in recent years [86].

The proportion of countries in which roundwood removals are likely to include sourcing from deforestation and clear-cutting areas was assessed (Figure 7). The findings of this assessment are supported by other sources such as the World Resource Institute [87], which underline that forest area loss due to clear-cutting procurement practices is happening at a large scale all over the planet. The loss of forest area always has an impact on the local environment and leads to a loss of ecosystem services [88,89]. The environmental impacts are particularly drastic when forest areas are permanently lost, as is the case in the categories of commodity-driven deforestation (CDD) and urbanization or over a long period (category of shifting agriculture-SA). Since the GFW category of forestry covers clear-cutting with subsequent reforestation, it leads to less drastic results than the other three categories, where forest is effectively lost. Our assessment shows that out of the 17 largest suppliers to the German TFP, around one third show a drastic loss of forest area in the categories CDD and SA between 2010 and 2015. The most notable case is Indonesia. Here, the forest area converted by yearly clear-cutting suggests so much harvesting that the calculated amount of wood sourced on these sites exceeds the officially reported roundwood removals by more than $125 \%$. This assessment indicates that Indonesia is probably an unsustainable source of roundwood and raises questions regarding the reliability of the official reports provided.

It can be assumed that wood procured on clear-cut or deforestation areas is subsequently used as material or energy. This wood would have to be clearly labeled as non-sustainable, regardless of whether it is used in the country or leaves the country via exports. Here, the responsibility lies with the trading partners to insist on a complete and transparent supply chain. However, the TFP or roundwood production of the respective country or region is by no means the sole driver of deforestation and can only be associated with these actions. Altogether, these results illustrate an interplay of various factors ranging from urbanization to the expansion of agricultural land and mining activities. It is therefore not possible to draw direct conclusions from the results about the exact contribution of the German TFP to forest area loss in other countries. The issue is addressed in a recent study [90] which examines the problem of traditional policy approaches and frameworks such as REDD+ and the Tropical Forest Alliance 2020 in relation to measures against deforestation, and it concludes that the complexity of the reasons for deforestation is often ignored and instead a broad discourse is advocated.

However, it is a positive development that the share of TFP from the above-mentioned "non-sustainable regions" in wood procurement has declined significantly in recent years (Asia-54\%, Africa-50\% and America-27\%). Brazil and Indonesia also show a decline 
in wood procurement for TFP of $-33 \%$ and $-51 \%$, respectively. This could lead to a theoretical relief of the (over-)used forest areas in these regions.

\subsection{Limitations of Current Approach and Way Forward}

The quantification of the Timber Footprint is so far limited to the spatial aggregation of Exiobase 3.4. Bjelle et al. [91] added country resolution (214 countries) to Exiobase, but only for land footprint accounts. Recently, Cabernard and Pfister [92] added spatial detail to Exiobase by combining it with the EORA database [93] and found that water stress and biodiversity loss in the EU increases by up to $20 \%$ by this measure. This highlights the large areas of uncertainty that still exist, especially for the vast Rest of the World regions. For future regular monitoring, it would be desirable to have a database with country resolution while maintaining high product resolution.

National forest inventories are the main data source for forest monitoring data presented in international programs such as the Global Forest Resource Assessment by the FAO and the assessment of the state of European forests (SOEF) [94]. However, the literature clearly indicates a great need for harmonization in the field of national forest inventories (NFI) $[41,95,96]$. A comprehensive study by Gschwantner et al. [41] shows great diversity regarding the criteria of country-specific national forest inventories. The survey methods differ not only in terms of tree parts included in the volume prediction but also in regard to the measurement of the dimensioning specifications used to calculate the available harvestable roundwood volume ( $\mathrm{dbh}$, stem top diameter, branch diameter and stump height thresholds) [97]. As a result, the data are not fully comparable between countries. However, the differences identified by Gschwantner et al. [41] are not considered in this study as they have not yet been implemented in the available official data.

The data sources used for this study all added method-specific uncertainties to the results presented [98-100]. There is no question that the level of detail of the statements could be increased by using higher-resolution information. The problem here is often the availability of necessary data [98]. For future research, it would be helpful to have access to better spatially resolved information on roundwood procurement areas, in addition to clear-cuts, in order to be able to allocate production volumes within different countries [101]. With additional information on the intensity of use of the respective forest area, the environmental impacts associated with roundwood extraction, such as biodiversity impact, could be localized more precisely.

In addition, it would be useful to include certification schemes and allocate the respective certified forest areas to the different countries in order to estimate the proportion of certified wood as a source for the TFP con. Topics such as security of supply, wood use potentials and global trade structures should be examined in the context of the future development of the bioeconomy. Additionally, factors such as consumer responsibility [102] and environmental justice [103] need to be analyzed more closely in the context of international responsibility for (sustainable) wood consumption, forest use and the SDGs [104], especially SDG 12 and SDG 15.

\section{Conclusions}

The main objective of this study was to deliver a comprehensive overview of the RE consumed by the German bioeconomy. The used method can account for RE inputs that were used abroad to produce products and services for German final consumption and are not (always) physically visible in the final product. The results are a discussionworthy supplement to those of the classical wood flow analysis on the methodical basis of material flow analysis [105]. Furthermore, the subsequent evaluation of the footprint clearly indicates whether roundwood procurement in an area or country of origin can be considered sustainable. The results show two different but strong dependencies of the German TFP. The first is the strong dependence on coniferous wood, which could become a problem in the coming years in view of the expected consequences of climate change. The second is the strong dependence on foreign imports of RE, which has increased 
during the period under study. In total, around half of Germany's total throughput of RE $\left(\mathrm{TFP}_{\mathrm{p}}\right)$ comes from abroad. The sustainability of imported RE is not always beyond doubt. Some of the countries or regions of origin significantly exceed the maximum amount of raw wood available under sustainable conditions (corresponding to the average growth). Africa, Brazil and South East Asia are particularly noteworthy in this respect. Furthermore, one third of the 17 largest suppliers of RE for the TFP sourced on foreign territory are very likely to use large proportions of roundwood procured through deforestation or from clear-cuts driven by agricultural expansion. Against this background, it is important to emphasize that, based on the data available for 2015, it would be possible to increase annual roundwood production in Germany by $8-41 \%$ (mainly in the hardwood sector) without violating the sustainability limits defined by the alternative WEHAM scenarios (HPS, NPS) and thus relieve the pressure of harvesting from other foreign regions.

Supplementary Materials: The following are available online at www.mdpi.com/xxx/s1, Supplementary Information I: This supplementary information provides the glossary of technical terms used in international and national forest inventories and the timber related terms of material flow analysis. Supplementary Information II: This supplementary information contains the net annual increment values for single countries and the Exiobase aggregation used to create Figure 6. The data are derived from the Global Forest Resource Assessment 2015, the State of Europe's Forest Report 2015, as well as the dissertation of O'Brien (2016). Supplementary Information III: This supplementary information provides the sources and data for the Roundwood Removal Adjustment value $R_{A}$ $22 \%$. Supplementary Information IV: The supplementary information SI provides the data for the Figures 2-7 from the main document.

Author Contributions: V.E.: Conceptualization, Methodology, Formal Analysis, Investigation, Writing-Original Draft, Visualization; G.V.: Conceptualization, Writing-Review and Editing; M.D.: Software, Data Curation, Writing-Review and Editing; F.S.: Writing—Review and Editing; R.H.: Data Curation; S.B.: Writing-Review and Editing, Supervision, Project Administration, Funding Acquisition. All authors have read and agreed to the published version of the manuscript.

Funding: This work was conducted within the scope of the project SYMOBIO (SYstemic MOnitoring and modelling of the German BIOeconomy), funded by the Federal Ministry of Education and Research (BMBF).

Institutional Review Board Statement: Not applicable.

Informed Consent Statement: Not applicable.

Data Availability Statement: Data are contained within the article or supplementary material.

Acknowledgments: The authors would like to thank the colleagues at the Center for Environmental Systems Research (CESR) in Kassel for their comments and suggestions, which improved the article.

Conflicts of Interest: The authors declare no conflict of interest.

\section{References}

1. International Resource Panel (IRP); Oberle, B.; Bringezu, S.; Hatfield-Dodds, S.; Hellweg, S.; Schandl, H.; Clement, J.; Cabernard, L.; Che, N.; Chen, D.; et al. Global Resources Outlook 2019-Natural Resources for the Future We Want; International Resource Panel: Nairobi, Kenya, 2019.

2. Weber, C.L.C.; Matthews, H.S.H. Food-Miles and the Relative Climate Impacts of Food Choices in the United States. Environ. Sci. Technol. 2008, 42, 3508-3513. [CrossRef]

3. Haberl, H.; Erb, K.-H.; Krausmann, F.; Berecz, S.; Ludwiczek, N.; Martínez-Alier, J.; Musel, A.; Schaffartzik, A. Using embodied HANPP to analyze teleconnections in the global land system: Conceptual considerations. Geogr. Tidsskr. J. Geogr. 2009, 109, 119-130. [CrossRef]

4. Erb, K.H.; Krausmann, F.; Lucht, W.; Haberl, H. Embodied HANPP: Mapping the spatial disconnect between global biomass production and consumption. Ecol. Econ. 2009, 69, 328-334. [CrossRef]

5. Steffen, W.; Richardson, K.; Rockström, J.; Cornell, E.; Fetzer, I.; Bennett, E.M.; Biggs, R.; Stephen, R.; De Vries, W.; De Wit, C.A.; et al. Planetary Boundaries: Guiding Human Development on a Changing Planet. Science 2015, 347, 1259855. [CrossRef] [PubMed]

6. European Comission. A Sustainable Bioeconomy for Europe: Strengthening the Connection between Economy, Society and the Environment. Updated Bioeconomy Strategy; European Commission: Brussels, Belgium, 2018. 
7. Bioökonomierat Was ist Bioökonomie? Available online: biooekonomierat.de/biooekonomie/ (accessed on 2 July 2020).

8. UN. Transforming Our World: The 2030 Agenda for Sustainable Development; United Nations, Department of Economic and Social Affairs: New York, NY, USA, 2015.

9. Egenolf, V.; Bringezu, S. Conceptualization of an Indicator System for Assessing the Sustainability of the Bioeconomy. Sustainability 2019, 11, 443. [CrossRef]

10. Smeets, E.; Weterings, R. Environmental Indicators: Typology and Overview; European Environment Agency: Copenhagen, Denmark, 1999.

11. Steinmann, Z.J.N.N.; Schipper, A.M.; Hauck, M.; Huijbregts, M.A.J.J. How Many Environmental Impact Indicators Are Needed in the Evaluation of Product Life Cycles? Environ. Sci. Technol. 2016, 50, 3913-3919. [CrossRef]

12. Steinmann, Z.J.N.; Schipper, A.M.; Hauck, M.; Giljum, S.; Wernet, G.; Huijbregts, M.A.J. Resource Footprints are Good Proxies of Environmental Damage. Environ. Sci. Technol. 2017, 51, 6360-6366. [CrossRef]

13. UN. The Sustainable Development Goals Report; UN: New York, NY, USA, 2017.

14. Jenkins, M.; Schaap, B. Forest Ecosystem Services—Background Analytical Study; UN: New York, NY, USA, 2018.

15. Brockerhoff, E.G.; Jactel, H.; Parrotta, J.A.; Quine, C.P.; Sayer, J. Plantation forests and biodiversity: Oxymoron or opportunity? Biodivers. Conserv. 2008, 17, 925-951. [CrossRef]

16. Thompson, I.D.; Okabe, K.; Tylianakis, J.M.; Kumar, P.; Brockerhoff, E.G.; Schellhorn, N.A.; Parrotta, J.A.; Nasi, R. Forest Biodiversity and the Delivery of Ecosystem Goods and Services: Translating Science into Policy. Bioscience 2011, 61, 972-981. [CrossRef]

17. Mori, A.S.; Lertzman, K.P.; Gustafsson, L. Biodiversity and ecosystem services in forest ecosystems: A research agenda for applied forest ecology. J. Appl. Ecol. 2017, 54, 12-27. [CrossRef]

18. Bonan, G.B. Forests and climate change: Forcings, feedbacks, and the climate benefits of forests. Science 2008, 320, 1444-1449. [CrossRef]

19. Nogueira, E.M.; Yanai, A.M.; Fonseca, F.O.R.; Fearnside, P.M. Carbon stock loss from deforestation through 2013 in Brazilian Amazonia. Glob. Chang. Biol. 2015, 21, 1271-1292. [CrossRef]

20. Harris, N.L.; Brown, S.; Hagen, S.C.; Saatchi, S.S.; Petrova, S.; Salas, W.; Hansen, M.C.; Potapov, P.V.; Lotsch, A. Baseline map of carbon emissions from deforestation in tropical regions. Science 2012, 336, 1573-1576. [CrossRef]

21. Mildrexler, D.J.; Zhao, M.; Running, S.W. A global comparison between station air temperatures and MODIS land surface temperatures reveals the cooling role of forests. J. Geophys. Res. Biogeosci. 2011, 116, 1-15. [CrossRef]

22. IPBES, S.; Díaz, J.; Settele, E.S.; Brondízio, E.S.; Hien, N.; Ngo, M.; Guèze, J.; Agard, A.; Arneth, P.; Balvanera, K.A.; et al. The Global Assessment Report on Biodiversity and Ecosystem Services—Summary for Policymakers; Intergovernmental Science-Policy Platform on Biodiversity and Ecosystem Services: Bonn, Germany, 2019.

23. Pimm, S.L.; Jenkins, C.N.; Abell, R.; Brooks, T.M.; Gittleman, J.L.; Joppa, L.N.; Raven, P.H.; Roberts, C.M.; Sexton, J.O. The biodiversity of species and their rates of extinction, distribution, and protection. Science 2014, 344. [CrossRef]

24. Buongiorno, J.; Zhu, S.; Raunikar, R.; Prestemon, J. Outlook to 2060 for World Forests and Forest Industries: A Technical Document Supporting the Forest Service 2010 RPA Assessment; US Department of Agriculture, Forest Service, Southern Research Station: Asheville, NC, USA, 2012.

25. Buongiorno, J. Global modelling to predict timber production and prices: The GFPM approach. Forestry 2014, 88, 291-303. [CrossRef]

26. FAO. State of the World's Forests 2009; Food and Agriculture Organization of the United Nations (FAO): Rome, Italy, 2009; ISBN 9789251060575.

27. Börjesson, P.; Hansson, J.; Berndes, G. Future demand for forest-based biomass for energy purposes in Sweden. For. Ecol. Manag. 2017, 383, 17-26. [CrossRef]

28. Anttila, P.; Nivala, V.; Salminen, O.; Hurskainen, M.; Kärki, J.; Lindroos, T.J.; Asikainen, A. Regional balance of forest chip supply and demand in Finland in 2030. Silva Fenn. 2018, 52, 1-20. [CrossRef]

29. EU Directive (EU) 2018/2001 of the European Parliament and of the Council on the Promotion of the Use of Energy from Renewable Sources; EU: Brussels, Belgium, 2018; Volume 2018.

30. Di Fulvio, F.; Forsell, N.; Korosuo, A.; Obersteiner, M.; Hellweg, S. Spatially explicit LCA analysis of biodiversity losses due to different bioenergy policies in the European Union. Sci. Total Environ. 2019, 651, 1505-1516. [CrossRef]

31. Huth, A.; Ditzer, T. Long-term impacts of logging in a tropical rain forest-A simulation study. For. Ecol. Manag. 2001, 142, 33-51. [CrossRef]

32. Kreutzweiser, D.P.; Hazlett, P.W.; Gunn, J.M. Logging impacts on the biogeochemistry of boreal forest soils and nutrient export to aquatic systems: A review. Environ. Rev. 2008, 16, 157-179. [CrossRef]

33. Sasaki, N.; Chheng, K.; Ty, S. Managing production forests for timber production and carbon emission reductions under the REDD+ scheme. Environ. Sci. Policy 2012, 23, 35-44. [CrossRef]

34. Marchi, E.; Picchio, R.; Spinelli, R.; Verani, S.; Venanzi, R.; Certini, G. Environmental impact assessment of different logging methods in pine forests thinning. Ecol. Eng. 2014, 70, 429-436. [CrossRef]

35. FAO; UNEP. The State of the World's Forests_Forests, Biodiversity and People; Food and Agriculture Organization of the United Nations (FAO): Rome, Italy, 2020.

36. Hosonuma, N.; Herold, M.; De Sy, V.; De Fries, R.S.; Brockhaus, M.; Verchot, L.; Angelsen, A.; Romijn, E. An assessment of deforestation and forest degradation drivers in developing countries. Environ. Res. Lett. 2012, 7. [CrossRef] 
37. Curtis, P.G.; Slay, C.M.; Harris, N.L.; Tyukavina, A.; Hansen, M.C. Classifying drivers of global forest loss. Science 2018, 361, 1108-1111. [CrossRef] [PubMed]

38. Astrup, R.; Bernier, P.Y.; Genet, H.; Lutz, D.A.; Bright, R.M. A sensible climate solution for the boreal forest. Nat. Clim. Chang. 2018, 8, 11-12. [CrossRef]

39. BMEL. Ergebnisse der Waldzustandserhebung 2020; BMEL: Bonn, Germany, 2021.

40. Forest Europe. State of Europe's Forests 2020; Forest Europe: Bratislava, Slovakia, 2020.

41. Gschwantner, T.; Alberdi, I.; Balázs, A.; Bauwens, S.; Bender, S.; Borota, D.; Bosela, M.; Bouriaud, O.; Cañellas, I.; Donis, J.; et al. Harmonisation of stem volume estimates in European National Forest Inventories. Ann. For. Sci. 2019, 76. [CrossRef]

42. FAO. Global Forest Resources Assessment 2015-Desk Reference, 2nd ed.; The Food and Agriculture Organization of the United Nations (FAO): Rome, Italy, 2015; ISBN 9789251088265.

43. Forest Europe. State of Europe's Forests 2015; Ministerial Conference on the Protection of Forests in Europe FOREST: Madrid, Spain, 2015.

44. FAO FAOSTAT. Available online: http://www.fao.org/faostat/en/\#home (accessed on 2 July 2020).

45. European Environment Agency (EEA) Forest Utilisation Rate per Country. Available online: https:/ / www.eea.europa.eu/dataand-maps/indicators/forest-growing-stock-increment-and-fellings-3/assessment (accessed on 22 March 2021).

46. Hansen, M.C.; Potapov, P.V.; Moore, R.; Hancher, M.; Turubanova, S.A.; Tyukavina, A.; Thau, D.; Stehman, S.V.; Goetz, S.J.; Loveland, T.R.; et al. Global Forest Change. Available online: https:/ / earthenginepartners.appspot.com/science-2013-globalforest (accessed on 21 February 2021).

47. Santoro, M. GlobBiomass-Global datasets of forest biomass. Pangeae 2018. [CrossRef]

48. FAO. Global Forest Resources Assessment 2020: Terms and Definition; FAO: Rome, Italy, 2018.

49. FAO. FRA 2015-Terms and Definitions; FAO: Rome, Italy, 2012.

50. FAO. Guide for Country Reporting for FRA 2015. FRA 2015, 51, 184.

51. European Communities. Economy-Wide Material Flow Accounts and Derived Indicators; European Communities: Luxembourg, Belgium, 2001.

52. Eurostat. Economy-Wide Material Flow Accounts_Handbook; Eurostat: Luxembourg, Belgium, 2018.

53. Kovanda, J.; Van De, S.I.; Schütz, H.; Bringezu, S. Economy-wide material flow indicators: Overall framework, purposes and uses and comparison of material use and resource intensity of the Czech Republic, Germany and the EU-15. Ecol. Indic. 2012, 17, 88-98. [CrossRef]

54. Schulze, E.-D.; Beck, E.; Buchmann, N.; Clemens, S.; Müller-Hohenstein, K.; Scherer-Lorenzen, M. Plant Ecology, 2nd ed.; Springer: Berlin/Heidelberg, Germany, 2019; ISBN 978-3-662-56231-4.

55. FAO. Forest Products Yearbook; FAO: Rome, Italy, 2018.

56. Persson, T.; Egnell, G. Stump harvesting for bioenergy: A review of climatic and environmental impacts in northern Europe and America. Wiley Interdiscip. Rev. Energy Environ. 2018, 7, 1-26. [CrossRef]

57. Stadler, K.; Wood, R.; Bulavskaya, T.; Södersten, C.J.; Simas, M.; Schmidt, S.; Usubiaga, A.; Acosta-Fernández, J.; Kuenen, J.; Bruckner, M.; et al. EXIOBASE 3: Developing a Time Series of Detailed Environmentally Extended Multi-Regional Input-Output Tables. J. Ind. Ecol. 2018, 22, 502-515. [CrossRef]

58. Peters, G.P.; Andrew, R.; Lennox, J. Constructing an environmentallyextended multi-regional input-output table using the gtap database. Econ. Syst. Res. 2011, 23, 131-152. [CrossRef]

59. Timmer, M.P.; Dietzenbacher, E.; Los, B.; Stehrer, R.; de Vries, G.J. An Illustrated User Guide to the World Input-Output Database: The Case of Global Automotive Production. Rev. Int. Econ. 2015, 23, 575-605. [CrossRef]

60. Lenzen, M.; Kanemoto, K.; Moran, D.; Geschke, A. Mapping the structure of the world economy. Environ. Sci. Technol. 2012, 46, 8374-8381. [CrossRef] [PubMed]

61. Exiobase Consortium Exiobase 3.4. Available online: https://www.exiobase.eu/index.php (accessed on 15 March 2020).

62. Miller, R.E.; Blair, P.D. Input-Output Analysis: Foundations and Extensions; Cambridge University Press: Cambridge, UK, 2009.

63. FAO. Global Fibre Supply Model; FAO: Rome, Italy, 1998.

64. O'Brien, M. Timber Consumption and Sustainable Forest Use; Kassel University Press: Kassel, Germany, 2016 ; ISBN 9783737601504.

65. Forest Europe; UNECE; FAO. State of Europe's Forests 2011; FOREST EUROPE Liaison Unit Oslo: Oslo, Norway, 2011.

66. FAO. State of the World's Forests 2011; FAO: Rome, Italy, 2011.

67. EEA. Environmental Indicator Report 2018; EEA: Copenhagen, Denmark, 2018.

68. Bundesministerium Für Ernährung und Landwirtschaft (BMEL). Der Wald in Deutschland—Ausgewählte Ergebnisse der Dritten Bundeswaldinventur; Bundesministerium für Ernährung und Landwirtschaft (BMEL): Berlin, Germany, 2014.

69. FAO. Statistical Pocketbook; FAO: Rome, Italy, 2018.

70. Hansen, M.C.C.; Potapov, P.V.; Moore, R.; Hancher, M.; Turubanova, S.A.A.; Tyukavina, A.; Thau, D.; Stehman, S.V.V.; Goetz, S.J.J.; Loveland, T.R.R.; et al. High-Resolution Global Maps of 21st-Century Forest Cover Change. Science 2013, 342, 850-853. [CrossRef]

71. Oehmichen, K.; Klatt, S.; Gerber, K.; Polley, H.; Röhling, S.; Dunger, K. Die alternativen WEHAM-Szenarien: Holzpräferenz, Naturschutzpräferenz und Trendfortschreibung. Szenarienentwicklung, Ergebnisse und Analyse; Thünen Report: Braunschweig, Germany, 2018.

72. UNECE. Potential Sustainable Wood Supply in Europe. Geneva Timber and Forest Discussion Paper; UNECE: Geneva, Switzerland, 2009; Volume 52. 
73. Weimar, H. Holzbilanzen 2013 bis 2015 Für die Bundesrepublik Deutschland; Thünen Working Paper: Hamburg, Germany, 2016; Volume 57.

74. Umweltbundesamt. Monitoringbericht 2015-Zur Deutschen Anpassungsstrategie an den Klimawandel-Bericht der Interministeriellen Arbeitsgruppe Anpassungsstrategie der Bundesregierung; Umweltbundesamt: Dessau-Roßlau, Germany, 2015.

75. Liu, C.L.C.; Kuchma, O.; Krutovsky, K.V. Mixed-species versus monocultures in plantation forestry: Development, benefits, ecosystem services and perspectives for the future. Glob. Ecol. Conserv. 2018, 15, e00419. [CrossRef]

76. Stadelmann, G.; Bugmann, H.; Meier, F.; Wermelinger, B.; Bigler, C. Effects of salvage logging and sanitation felling on bark beetle (Ips typographus L.) infestations. For. Ecol. Manag. 2013, 305, 273-281. [CrossRef]

77. Komonen, A.; Schroeder, L.M.; Weslien, J. Ips typographus population development after a severe storm in a nature reserve in southern Sweden. J. Appl. Entomol. 2011, 135, 132-141. [CrossRef]

78. Schroeder, L.M. Colonization of storm gaps by the spruce bark beetle: Influence of gap and landscape characteristics. Agric. For. Entomol. 2010, 12, 29-39. [CrossRef]

79. Wald und Holz NRW Praxisleitfaden Fichten Borkenkäfer: Erkennen-Bekämpfen-Vorbeugen; Wald und Holz NRW: Münster, Germany, 2019.

80. BMEL. Ergebnisse der Waldzustandserhebung 2019; BMEL: Bonn, Germany, 2019.

81. Millar, C.I.; Stephenson, N.L. Temperate forest health in an era of emerging megadisturbance. Science 2015, 349, 823-826. [CrossRef]

82. Buras, A.; Rammig, A.; Zang, C.S. Quantifying impacts of the drought 2018 on European ecosystems in comparison to 2003. Biogeosciences 2019. [CrossRef]

83. Schuldt, B.; Buras, A.; Arend, M.; Vitasse, Y.; Beierkuhnlein, C.; Damm, A.; Gharun, M.; Grams, T.E.E.; Hauck, M.; Hajek, P.; et al. A first assessment of the impact of the extreme 2018 summer drought on Central European forests. Basic Appl. Ecol. 2020, 45, 86-103. [CrossRef]

84. Umweltbundesamt. Indikator-Factsheet: Mischbestände FW-R-1; Umweltbundesamt: Dessau-Roßlau, Germany, 2017.

85. Umweltbundesamt. Indikator-Factsheet: Förderung des Waldumbaus; Umweltbundesamt: Dessau-Roßlau, Germany, 2019.

86. Ceccherini, G.; Duveiller, G.; Grassi, G.; Lemoine, G.; Avitabile, V. Abrupt Increase in Forest Harvested Area over Europe After 2015 Nature. Nature 2020, 583. (In Press) [CrossRef]

87. World Resource Institute; Weisse, M.; Dow Goldman, E. The World Lost a Belgium-Sized Area of Primary Rainforests Last Year. Available online: https:/ / www.wri.org/blog/2019/04/world-lost-belgium-sized-area-primary-rainforests-last-year (accessed on 19 November 2020).

88. Lawrence, D.; Vandecar, K. Effects of tropical deforestation on climate and agriculture. Nat. Clim. Chang. 2015, 5, 27-36. [CrossRef]

89. Franco, A.L.C.; Sobral, B.W.; Silva, A.L.C.; Wall, D.H. Amazonian deforestation and soil biodiversity. Conserv. Biol. 2019, 33, 590-600. [CrossRef]

90. Delabre, I.; Boyd, E.; Brockhaus, M.; Carton, W.; Krause, T.; Newell, P.; Wong, G.Y.; Zelli, F. Unearthing the myths of global sustainable forest governance. Glob. Sustain. 2020. [CrossRef]

91. Bjelle, E.L.; Többen, J.; Stadler, K.; Kastner, T.; Theurl, M.C.; Erb, K.H.; Olsen, K.S.; Wiebe, K.S.; Wood, R. Adding country resolution to EXIOBASE: Impacts on land use embodied in trade. J. Econ. Struct. 2020, 9. [CrossRef]

92. Cabernard, L.; Pfister, S. A highly resolved MRIO database for analyzing environmental footprints and Green Economy Progress. Sci. Total Environ. 2021, 755. [CrossRef] [PubMed]

93. Lenzen, M.; Kanemoto, K.; Moran, D.; Geschke, A. EORA. Available online: http://www.worldmrio.com/ (accessed on 5 November 2018).

94. Vidal, C.; Alberdi, I.A.; Mateo, L.H.; Redmond, J.J. National Forest Inventories-Assessment of Wood Availability and Use; Springer Link: Cham, Swizerland, 2016; ISBN 978-3-319-44015-6.

95. Alberdi, I.; Bender, S.; Riedel, T.; Avitable, V.; Boriaud, O.; Bosela, M.; Camia, A.; Cañellas, I.; Castro Rego, F.; Fischer, C.; et al. Assessing forest availability for wood supply in Europe. For. Policy Econ. 2020, 111, 102032. [CrossRef]

96. Mubareka, S.; Vacchiano, G.; Pilli, R.; Hilferink, M.; Fiorese, G. Integrated modelling approach to assess woody biomass supply, demand and environmental impacts of forest management in the EU. In Proceedings of the 9th International Congress on Environmental Modelling and Software, Fort Collins, CO, USA, 24-28 June 2018.

97. Gschwantner, T.; Schadauer, K.; Vidal, C.; Lanz, A.; Tomppo, E.; Di Cosmo, L.; Robert, N.; Duursma, D.E.; Gschwantner, M.L.; Schadauer, T.; et al. Common Tree Definitions for National Forest Inventories in Europe. Silva Fenn. 2009, 43. [CrossRef]

98. Kallio, A.; Solberg, B. On the Reliability of International Forest Sector Statistics: Problems and Needs for Improvements. Forests 2018, 9, 407. [CrossRef]

99. Rodrigues, J.F.D.; Moran, D.; Wood, R.; Behrens, P. Uncertainty of Consumption-Based Carbon Accounts. Environ. Sci. Technol. 2018, 52, 7577-7586. [CrossRef]

100. Santoro, M.; Cartus, O.; Carvalhais, N.; Rozendaal, D.; Avitabilie, V.; Araza, A.; de Bruin, S.; Herold, M.; Quegan, S.; Rodríguez Veiga, P.; et al. The global forest above-ground biomass pool for 2010 estimated from high-resolution satellite observations- SI. Earth Syst. Sci. Data Discuss. 2020, 1-38. [CrossRef]

101. Jucker, T.; Caspersen, J.; Chave, J.; Antin, C.; Barbier, N.; Bongers, F.; Dalponte, M.; van Ewijk, K.Y.; Forrester, D.I.; Haeni, M.; et al. Allometric equations for integrating remote sensing imagery into forest monitoring programmes. Glob. Chang. Biol. 2017, 23, 177-190. [CrossRef] [PubMed] 
102. Landrigan, P.J.; Fuller, R.; Acosta, N.J.R.; Adeyi, O.; Arnold, R.; Basu, N. (Nil); Baldé, A.B.; Bertollini, R.; Bose-O’Reilly, S.; Boufford, J.I.; et al. The Lancet Commission on pollution and health. Lancet 2017, 391, 462-512. [CrossRef]

103. Ramirez-Andreotta, M. Environmental justice. Env. Pollut. Sci. 2019, 573-583. [CrossRef]

104. United Nations. Global Sustainable Development Report, 2015th ed.; United Nations: New York, NY, USA, 2015.

105. Mantau, U. Wood flow analysis: Quantification of resource potentials, cascades and carbon effects. Biomass Bioenergy 2015, 79, 28-38. [CrossRef] 